Article

\title{
The Role of Cultural Heritage in Sustainable Development: Multidimensional Indicators as Decision-Making Tool
}

\author{
Francesca Nocca ${ }^{1,2}$ \\ 1 Interdepartmental Research Centre in Urban Planning "Alberto Calza Bini”, \\ University of Naples Federico II, Via Toledo 402, 80132 Naples, Italy; francesca.nocca@unina.it \\ 2 Italian Scientific Committee on Economics of Conservation (ISCEC), International Council on Monuments \\ and Sites (ICOMOS), Via Toledo 402, 80132 Naples, Italy
}

Received: 25 September 2017; Accepted: 13 October 2017; Published: 19 October 2017

\begin{abstract}
The concept of sustainable development has been the main topic of many international conferences. Although many discussions are related to the role of cultural heritage in sustainable development, they develop only on theoretical level. The answer to the main question, that is if the cultural landscape can play a role in sustainable development, could be positive only if we are able to produce empirical evidence about its contribution to improve economic, social, and environmental productivity of the city. It is necessary to produce empirical evidence to demonstrate that cultural heritage conservation/valorization is an investment and not a cost. To date, there are few researches about the indicators that are able to support the relationship between cultural heritage conservation/regeneration and sustainable development. This paper intends to go beyond this limit and approach this issue in operational terms. It is focused on the role that cultural heritage can play in the sustainable development framework. An assessment framework that is able to capture the multidimensional benefits of cultural landscape conservation/valorization is proposed here starting from the analysis of 40 case studies of culture-led regeneration projects. A matrix of multidimensional indicators (divided into nine categories) about the impacts produced by these 40 cultural heritage conservation/valorization projects and its critical analysis is here proposed, mainly focusing the attention on the double relationship between the tourism sector and climate change. Although the analyses often refer to sustainability, it is not concretely addressed because there is an imbalance among the dimensions: in most cases, only the economic component is highlighted, leaving out the social and environmental dimensions. Furthermore, the impacts related to cultural-led projects are mainly interpreted in terms of tourism and real estate impacts.
\end{abstract}

Keywords: cultural urban landscape; multidimensional indicators; tourism-climate change relationship; circular tourism

\section{Sustainable Development and Circular Economy}

The concept of sustainable development has been the main topic of many international conferences. It dates back to 1970s, when the awareness of the risk of the natural systems' collapse began to spread as a consequence of the traditional development associated exclusively to the economic growth. Only considering economic development is no longer sufficient, as such more attention began to be focused on environmental and social issues.

The most common definition of sustainability is provided in 1987 by the World Commission on Environment and Development in the "Our Common Future" report (well-known as Brundtland Report). It defines sustainability as "a process aimed at achieving environmental, economic and social improvement, both locally and globally, or a state that can be maintained at 
a certain level indefinitely. This process binds in a relationship of interdependence, the protection and enhancement of natural resources to the economic, social, in order to meet the needs of the present generation, without compromising the ability of future generations to meet their own needs. So it is incompatible with the degradation of heritage and natural resources, but also with the violation of human dignity and human freedom, with poverty and economic decline, with the lack of recognition of the rights and equal opportunities" [1].

According to this definition, the concept of sustainability is connected to the compatibility between the economic development and environmental protection. Furthermore, it emphasizes the role of development to ensure the satisfaction of the present generation's needs, without compromising, at the same time, the possibility of future generations to achieve them (intergenerational responsibility in the use of resources). This perspective recalls the need to combine the three of the fundamental dimensions of development: environmental, economic, and social dimension [1,2].

The means to operationalize sustainable development (through an action plan) have been discussed during the United Nations Conference on Environment and Development, held in Rio de Janeiro in 1992 (Earth Summit).

Rio acts, and the subsequent world conferences promoted by the United Nations (UN) (especially the Johannesburg Conference in 2002), confirmed the configuration of the principle of sustainable development based on three interdependent factors: environmental protection, economic growth, and social development.

Clear and practical measures for implementing sustainable development and reconciling the economic and environmental goals of the global community have been at the core of the United Nations Conference on Sustainable Development, also known as Rio 2012, Rio+20 [2].

In September 2015, the 2030 Agenda for Sustainable Development has been defined by the governments of the $193 \mathrm{UN}$ member countries [3].

This action plan "for people, planet and prosperity" aims to take transformation measures to shift the world towards a sustainable and resilient future.

At the core of the 2030 Agenda there are 17 Sustainable Development Goals (SDGs), for a total of 169 targets [3] covering the three dimensions of sustainable development. They represent a new effort/commitment that involves all of the countries in the economic, social, environmental sustainability for 15 years, until 2030, replacing the Millennium Development Goals (MDGs), approved by United Nation in 2000, whose deadline was scheduled for December 2015 [4].

The concept of sustainable development has been discussed also during the Habitat Process: Vancouver in 1976 (Habitat I), Istanbul in 1996 (Habitat II), and Quito in 2016 (Habitat III). This process was born from the need to face problems resulting from increasing urbanization.

While Habitat I Conference has been concentrated on housing supply (at a technical level), the Istanbul Conference (Habitat II) has drawn attention to the Earth Summit in Rio de Janeiro (1992) that focused its attention on sustainable development. The Habitat Agenda, one of the outcome documents of Habitat II conference [5], has been focused in particular on the necessity to provide everyone with adequate housing.

Habitat III (formally known as the United Nations Conference on Housing and Sustainable Urban Development) represents the most recent global effort to identify a shared vision for the sustainable future of the cities. The core of the discussion of this global summit, which was held in Quito (Ecuador) on 17-20 October 2016, has been the achievement of equity and sustainability, both being economic and social and environmental.

The concept of sustainable development is included in Habitat III Conference recognizing economic and social development as a part of an interconnected system of balances, highlighting that progress in one area can produce negative impacts in another one (as already anticipated by the World Commission on Environment and Development).

The aim of Habitat III Conference has been to strengthen the global political commitment to the achievement of sustainable development of cities and other human settlements, both rural and urban. 
The outcome document of the conference is the New Urban Agenda, defining the global urbanization strategies for the next two decades. The aim of the Agenda is thus to guide, for the next 20 years, the efforts around urbanization.

Unlike the 2015 United Nations Climate Change Conference COP 21 [6] and the Marrakech climate change conference COP22 [7], the New Urban Agenda is not binding. It represents only a guide to a wide range of actors (as nations, city and regional authorities, civil society, foundations, NGOs, academic researchers, and U.N. Agencies).

In order to achieve sustainability, the circular economy can be considered as a promising approach [8,9]. McDonough and Braungart (2013) have highlighted that current eco-efficient strategies for achieving sustainability goals are "still supporting the linear production system, only stretching the line", and they are mainly focused on the reduction of impacts on the environmental system [10]. Instead, it is necessary to focus also on the effectiveness of the systems. In this perspective, the circular economy $[8,9,11]$ can represent a tool for achieving and implementing sustainable development, minimizing negative impacts, and producing benefits (related to environmental, economic, and socio-cultural systems [12]).

Furthermore, although many discussions are related to the role of cultural heritage in sustainable development, they develop only on the theoretical level.

This paper wants to go beyond this limit and approach this issue in operational terms. It is focused on the role that local heritage (that determines the cultural heritage) can play in this sustainable development framework.

After the analysis of official documents dealing with the relationship between cultural heritage and sustainable development, the need for operational tools is highlighted.

In this research, starting from the analysis of 40 case studies, a matrix of multidimensional indicators about the impacts produced by cultural heritage conservation/regeneration projects is elaborated and critically analysed. The impact indicators are divided into nine categories (and related sub-categories), highlighting the multidimensional impacts produced by cultural-led regeneration projects.

\section{The Role of Cultural Heritage in the Achievement of Sustainable Development}

\subsection{The Role of Cultural Heritage in 2030 Agenda for Sustainable Development and the New Urban Agenda}

Cultural heritage plays a marginal role in the 2030 Agenda for Sustainable Development. It is explicitly mentioned only once in the goal 11 , that is referred to the cities, in particular to the need of making cities and human settlements "inclusive, safe, resilient and sustainable", through "inclusive and sustainable urbanization, planning and management" (Target 11.3) and more "efforts to protect and safeguard the world's cultural and natural heritage" (Target 11.4).

In particular, cultural heritage is mentioned in the Target 11.4 ("strengthen efforts to protect and safeguard the world's cultural and natural heritage"), one out of 169 targets. However, it is a weak reference because it is not specific on cultural heritage, but it is mentioned together with natural one; furthermore, this specific target deals only with the protection and safeguard of cultural heritage, without any reference to its valorization/regeneration.

The New Urban Agenda (NUA) [13] recognizes cultural heritage as an important factor for urban sustainable development. There are a lot of points highlighting the role of cultural heritage (both tangible and intangible) in the urban sustainable development.

Culture should be taken into account to promote and implement the sustainable consumption and production patterns (point 10). It is considered as a key element in the humanization of cities and human settlements (point 26), playing an important role "in rehabilitating and revitalizing urban areas, and in strengthening social participation and the exercise of citizenship" (point 38). 
Furthermore, NUA highlights the role of cultural heritage in developing vibrant, sustainable, and inclusive urban economies, and in sustaining and supporting urban economies to progressive transition towards higher productivity (points 45 and 60).

Culture is recognized "as a priority component of urban plans and strategies in the adoption of planning instruments, including master plans, zoning guidelines, building codes, coastal management policies, and strategic development policies that safeguard a diverse range of tangible and intangible cultural heritage and landscapes"; so, it is necessary to "protect them from potential disruptive impacts of urban development" (point 124).

Moreover, some international organizations, as UNESCO and ICOMOS (International Council on Monuments and Sites), highlight the key role of culture in the achievement of sustainable development $[14,15]$.

As Throsby highlights, the economic, social, cultural and environmental systems are not isolated, but they are "interconnected" (principle of interconnectedness-[16]). Cultural heritage can be considered as the "glue" among the different dimensions of sustainable development [17].

\subsection{The Complex Urban Landscape and the Landscape Approach}

The definition of Historic Urban Landscape (HUL) [18] is the latest specific contribution of the international debate on the identification, conservation, and enhancement of cultural heritage.

The Historic Urban Landscape, that is the "historic layering of cultural and natural values and attributes" (art. 8), incorporates the intangible dimension of heritage and the related economic processes.

This approach recognizes the necessity to support the protection/safeguard/conservation/valorization of cultural and natural heritage in a world characterized by rapid and uncontrolled urbanization, integrating heritage conservation into the transformation strategies and projects.

The attention has moved from the "monument" to the context, to the recognition of the importance of social, cultural, and economic processes in the conservation of urban areas [13] (art. 4).

The 2011 UNESCO Recommendation on Historic Urban Landscape [18] recognizes the landscape as a "living heritage", an "organism" made of complex characters, relationships and multidimensional inter-relationships [19]. It refers to the notion of context to emphasize the systemic interrelationship among economic, social, environmental, cultural aspects, and the complexity of the framework within which conservation policies lie.

So, the values of cultural heritage are based on a complex vision that considers the Complex Social Value of a resource [20,21].

In the same perspective, the European Commission has recognized cultural heritage as a common good using, for the first time in an institutional context, the notion of "intrinsic and social value of heritage" (Section 2.1) [9]. Cultural heritage is recognized as a strategic resource for sustainable development, as a key element in the global competition.

The European Commission has highlighted the need to go "towards an integrated approach to cultural heritage for Europe", recognizing the different dimensions (cultural, physical, environmental, human, and social) and values (both intrinsic and economic) of cultural heritage.

The intrinsic value of cultural landscape can be expressed through the Complex Social Value [20]. Here, the conflicts among different values (economic, social, financial, environmental, symbolic, cultural ones) are very concentrated and should be managed.

The HUL approach places the heritage conservation in a new systemic vision that links tradition and modernization, present and past, present and future, in a circular and synergistic perspective.

The "Historic Urban Landscape" [18] can be interpreted as the result of the dynamic interaction among six different landscapes.

The "complex urban landscape" is considered as the combination of the following six perceived landscapes and, at the same time, the interaction among them [22]: 
- Natural landscape consists of existing natural capital (biomass, biodiversity, parks and urban corridors, agricultural areas, natural resources, lakes, rivers, energy resources, etc.) that geographically and territorially characterizes a city.

- Infrastructure man-made landscape is composed of built infrastructures and equipment systems (roads, ports, airports, bike paths, housing, public spaces, etc.) that are able to improve the quality of people's life, to promote social welfare, and the economic development (improving economies of agglomeration, scale, reducing transportation costs, etc.).

- Cultural man-made landscape comes out over the centuries. It is the heritage (cultural memory) of past generations that have to be transferred to future generations (historic centres, etc.) as a fundamental element of identity.

- Social landscape is composed of social/civil networks, density of associations, third sector, voluntary sector, etc.

- Human landscape reflects the expertise, local knowledge, local entrepreneurship, creativity of individuals. It helps to determine "human scale" of settlement.

- Financial-Economic landscape consists of local credit institutions, foundations, co-operative banks, third sector organizations, institutions that promote financing of district projects (promoted by inhabitants, etc.), etc.

All of the values/goals/interests of a society are reflected in the landscape that can be considered the synthetic indicator of the sustainability [22].

Some of the above-mentioned six landscapes are in a mutual relationship with each other and the specific character of a city, its identity (and thus its attractiveness), the spirit of a place rise from the specific combination of them [23].

The high quality of the complex landscape contributes to the enhancement of city attractiveness through more dense circular, synergistic and symbiotic processes. Therefore, it is able to stimulate a new demand and a new development perspective [22].

Considering the landscape as a complex and living system requires a multidimensional assessment approach. The complex social value of the landscape requires monetary and non-monetary, quantitative, and qualitative indicators.

In this perspective, integrated evaluation tools are required. An economic approach is necessary, but it is not sufficient: the quantitative economic matrix has to be enriched with qualitative indicators, expressed by social component (social matrix) and environmental component (ecological matrix).

An assessment framework that is able to capture the multidimensional benefits of cultural landscape conservation/regeneration is proposed in the following paragraphs, starting from the analysis of 40 case studies of culture-led regeneration projects (see the following paragraphs and [24]).

\section{The Need to Move from Principles to Action: Means of Implementation}

\subsection{International Research about Cultural Heritage Indicators}

Both the 2030 Agenda for Sustainable Development [3] and the New Urban Agenda [13] focus on the need to move from principles to actions.

The 2030 Agenda dwells on the necessity of adequate evaluation tools, highlighting the central role of evaluation processes in the achievement of all goals $(80,94,104,115,136,138,147,158,159,161$, 172 paragraphs).

Also, in the Means of Implementation section of the New Urban Agenda (points 126-160) the necessity of a variety of actors and means to implement the complex agenda is recognized. A wide range of financial, planning, and evaluation tools is required.

The necessity to generate evidence-based and practical guidance for implementation (point 128), property value assessment promoting best practices to capture the increase in land and property value due to urban development processes and investments (point 137), impact an assessment of investments 
and projects (point 138), the capacity to formulate, implement, enhance, manage, monitor, and evaluate public policies for sustainable urban development (point 147) are a part of the main means.

In the campaign for promoting the Transforming Our World (2015), it is recognized that "the narrative on culture and sustainable development must be strengthened with evidence-based research and indicators. There is a need for reliable and inclusive indicators to measure the implementation of the culture related targets". It is stated the commitment "to the design of cultural indicators and a suitable information infrastructure which allows for a better quantitative and qualitative understanding and measurement of the place of culture in sustainable development".

However, for decades researchers and practioners have claimed that cultural heritage conservation produces multidimensional benefits, but this assertion has not been usually supported by robust analyses.

Cultural heritage is too often left out of development programs of cities. It should assume a more central role and should be well managed.

The answer to the main question, that is whether cultural landscape can play a role in sustainable development, could be positive only if we are able to produce empirical evidence about its contribution to improve economic, social, and environmental productivity of the city [23]. In this study, the multidimensional benefits produced by cultural landscape regeneration are highlighted through the analysis of 40 case studies [24].

It is important to convince public, private, and social actors about the convenience (economic, social, environmental benefits) of cultural heritage integrated conservation. It is necessary to produce empirical evidence to demonstrate that cultural heritage conservation/valorization is an investment and not a cost.

Debates and discussions, and a set of good practices are able to give empirical evidence supporting the transition from theories to actions and, therefore, to improve decision making processes.

It needs to demonstrate the multidimensional impacts (economic impacts, but also social and environmental ones) of investments in cultural heritage in order to convince about its capacity to contribute to increase the overall local productivity, to improve wellbeing of inhabitants and to attract funding from the public, private and private-social sectors.

This multidimensional perspective implies a systemic and integrated conservation approach, requiring assessment tools (methods, indicators, etc.) able to compare the costs of conservation of the past with the benefits of the change.

To date, there are few researches about indicators able to support the relationship between cultural heritage conservation/regeneration and development.

Although the role of cultural heritage in sustainable development has been recognized in the international debate about Sustainable Development Goals (SDGs), it is explicitly mentioned only once in the Goal 11 (Target 11.4) and, to date, only one indicator has been identified about it, as the result of a series of public consultations with agencies and organizations. It is the indicator 11.4.1, aiming to illustrate how financial efforts/actions made by public authorities at different levels (local, national, and international levels), alone or in partnership (for example, with civil society organizations and private sector), to protect and safeguard cultural heritage have a direct impact in making cities and human settlements more sustainable. "This means that cultural resources and assets are safeguarded to keep attracting/to attract people (inhabitants, workers, tourists, etc.) and financial investments, to ultimately enhance the total amount of expenditure" (www.unhabitat.org).

However, only one indicator (based on the expenditure per capita) is an oversimplification that is too much limiting and it is not effective to achieve the goal 11.4 of SDGs.

It is not specific to cultural heritage, but the latter is mentioned together with the natural one. There are also some methodological problems related to this indicator. For example, the expenditure per capita is not comparable among each country. Furthermore, it is not clear how to quantify it, which data should be used, which are the data sources. This indicator does not highlight the impacts 
that cultural landscape has on city productivity; it is not useful to assess multidimensional benefits that it is able to produce. It needs to be drastically improved.

The identification of further indicators able to provide an effective assessment of benefits that are produced by integrated conservation is necessary.

In this framework, UNESCO and ICOMOS have recognized the need of an additional set of indicators and adequate evaluation tools able to assess and monitor the contribution of cultural heritage to the achievement of the goal 11 and, more in general, of sustainable development.

These indicators are necessary to assess the multidimensional "productivity" of cultural heritage conservation/regeneration and to allow for replication and scaling-up of successful practices. They are required to identify and evaluate the economic value of cultural heritage and to convert its "soft" values in monetary ones. They "express how economic value may be consistent with sustainable development goals" [25].

The indicators related to cultural heritage should reveal authenticity, integrity and cultural values and, at the same time, monitor impacts on tourism sector, environmental capital, community wellbeing, etc. [26,27]. In other words, these indicators have to be used to assess and monitor the state of conservation of cultural heritage, but also to evaluate the impacts of cultural heritage conservation/regeneration on city multidimensional productivity, that is its contribution to sustainable development. These impacts have been highlighted through the analysis of 40 case studies, showed in the following paragraphs.

However, empirical evidence about multidimensional benefits of cultural heritage conservation/regeneration (and so its contribution to sustainable development) is still lacking and requires a holistic approach. For example, ChCfe report highlights that only $6 \%$ of the case studies (that they have been analysed) has been conceived as "holistic" study covering the four domains (economic, social, cultural, and environmental) [28].

\subsection{Multidimensional Impacts of Cultural Landscape Conservation/Regeneration: A Critical Analysis of 40 Case Studies}

A set of indicators to assess the role of culture in sustainable development (and thus the multidimensional benefits produced by cultural heritage conservation/valorization) is urgently required.

In this perspective, the evaluation approaches have been reviewed starting from the evaluation deduced from actual case studies.

Good practices have been analysed to construct a multidimensional indicators matrix that is able to evaluate multidimensional impacts of heritage conservation/regeneration [24].

The processing of the database of good practices (from all over the world) has been developed to deduce indicators for recomposing the indicators matrix that can produce empirical evidence about impacts of cultural landscape conservation/regeneration projects and its contribution to sustainable development.

In order to understand which are the impacts produced by cultural landscape conservation/regeneration on city productivity and related indicators, 40 case studies have been analysed [24]: Bath (UK), Edinburgh (UK), Glasgow (Scotland), Guimares (Portugal), Huntsville (AL, USA), Istanbul (Turkey), Kazimierz/Kracow (Poland), Kosice (Slovakia), Lille (France), Linz (Austria), Liverpool (UK), Luxembourg (Luxembourg), Maribor (Slovenia), Marrakesh (Morocco), Marseille (France), Mons (Belgium), Newcastle (UK), Oaxaca de Juarez (Mexico), Oporto (Portugal), Ottawa (Canada), Pecs (Hungary), Perth (Australia), Philadelphia (PA, USA), Pilsen (Czech Republic), Plymouth (England), Quito (Ecuador), Riga (Lettonia), Ruhr (Germany), Salford/Manchester (England), Salvador de Bahia (Brazil), Sibiu (Romania), Skopje (Macedonia), Stavanger (Norway), Tallin (Estonia), Tiblisi (Georgia), Turku (Finland), Umea (Sweden), Valparaiso (Chile), Verona (Italy), and Vilnius (Lithuania).

Scientific papers and reports have been selected and analysed to gather data and information about each case study. They are mainly selected on the base of data availability (good practices with 
the greatest number of available data), has been deeply analyzed and a summarizing sheet about impact indicators has been elaborated for each of them [24].

The indicators to assess the "productivity" of cultural heritage conservation/regeneration of the 40 analysed case studies, that is the multidimensional benefits produced, have been subdivided into nine impact categories that compose the comprehensive matrix for impact assessment [24]:

1. Tourism and recreation

2. Creative, cultural and innovative activities

3. Typical local productions

4. Environment and natural capital

5. Social capital/cohesion and inclusion

6. Real estate

7. Financial return

8. Cultural value of properties/landscape

9. Wellbeing

These categories are interdependent and related to impacts both on cultural heritage and from cultural heritage. Each impacts category is, in turn, composed of sub-categories of indicators (Tables 1-11).

Table 1. Impact categories and related indicator categories.

\begin{tabular}{ll}
\hline Impact Categories & Indicator Categories \\
\hline \multirow{2}{*}{ Tourism and recreation } & Touristic demand \\
& Touristic supply \\
& Economic vitality \\
& Economic impact on local wealth \\
\hline \multirow{2}{*}{ Creative, cultural and innovative activities } & Cultural demand \\
& Cultural supply \\
& Economic vitality \\
& Economic impact on local wealth \\
& Employment in cultural activities \\
\hline \multirow{3}{*}{ Typical local productions } & Creative firms \\
& Local production \\
Environment and natural capital & Employment in local production \\
\hline & Environmental preservation \\
Social capital/cohesion and inclusion & Green areas and facilities supply \\
& Social cohesion \\
& Sharing/collaborative economy initiatives \\
\hline \multirow{2}{*}{ Real estate } & Employment \\
& Social inclusion \\
\hline Financial return & Real estate value \\
\hline Cultural value of properties/landscape & Real estate supply (N. of residences, commercial units, etc.) \\
(N. of well-preserved/in ruin buildings) & Real estate development \\
\hline & Public financial return \\
\hline & State of conservation of heritage/landscape asset \\
\hline
\end{tabular}

Source: Case studies [24]. 
Table 2. Number of indicators for each category.

\begin{tabular}{lc}
\hline \multicolumn{1}{c}{ Impact Categories } & N. of Indicators \\
\hline Tourism and recreation & 56 \\
Creative, cultural and innovative activities & 28 \\
Typical local productions & 7 \\
Environment and natural capital & 3 \\
Social capital/cohesion and inclusion & 28 \\
Real estate & 25 \\
Financial return & 9 \\
Cultural value of properties/landscape & 14 \\
Wellbeing & 7 \\
Total & 177 \\
\hline
\end{tabular}

Table 3. Tourism and recreation.

\begin{tabular}{|c|c|c|c|}
\hline & Tourism and Recreation Indicators & & \\
\hline Category & Indicator & Unit of Measure & Frequency Analysis \\
\hline Touristic demand & N. of visitors per year (or per day) & n./year (or day) & 22 \\
\hline Touristic demand & N. (or percentage) of visitors staying overnight & n./year (or \%/year) & 8 \\
\hline Touristic demand & Visitors average length of stay & n. nights/person/year & 7 \\
\hline Touristic demand & Average growth rate of number of visitors & $\%$ & 9 \\
\hline Touristic demand & Average growth rate (or number) of nights spent by tourists & $\%$ (or $n$.) & 9 \\
\hline Touristic demand & N. of tourists per business per day (restaurants, cafes, shops) & n./day & 3 \\
\hline Touristic demand & Percentage of crowding in restaurants & $\%$ & 1 \\
\hline Touristic demand & Visitors' expenditure & $€ /$ day; $€ /$ year & 11 \\
\hline Touristic demand & $\begin{array}{l}\text { Total spend of daily visitors (in stores, restaurants, } \\
\text { accommodations, etc.) }\end{array}$ & $€ /$ day; $€ /$ year & 7 \\
\hline Touristic demand & Total spend of staying visitors & $€ /$ day; $€ /$ year & 2 \\
\hline Touristic demand & Average daily expenditure of users for travel & $€ /$ day & 1 \\
\hline Touristic demand & $\begin{array}{l}\text { Percentage of annual direct visitors expenditure attributed } \\
\text { to cultural heritage }\end{array}$ & $\%$ & 1 \\
\hline Touristic demand & $\begin{array}{l}\text { Percentage of spending of heritage tourists compared with } \\
\text { spending of other tourists }\end{array}$ & $\%$ & 1 \\
\hline Touristic demand & N. (or percentage) of one-day trips & n./year (or \%/year) & 2 \\
\hline Touristic demand & Percentage of tourists on repeat visit to the city & $\%$ & 1 \\
\hline Touristic demand & Occupancy rate of touristic units & $\%$ & 7 \\
\hline Touristic demand & N. of people in hotels & n./year & 2 \\
\hline Touristic demand & N. of visitors to tourist information offices & N./day (or n./year) & 2 \\
\hline Touristic demand & N. of tickets sold for touristic place of interest & n./day (or year) & 1 \\
\hline Touristic demand & Percentage (or number) of national tourists & $\%$ (or n.) & 9 \\
\hline Touristic demand & $\begin{array}{l}\text { Percentage (or number) of international tourists } \\
\text { (internationalization) }\end{array}$ & $\%$ (or n.) & 10 \\
\hline Touristic demand & N. (or percentage) of airline/train/cruise passengers & n./years & 5 \\
\hline Touristic demand & Percentage of increase in airline/train/cruise passengers & $\%$ & 1 \\
\hline Touristic demand & N. of organised trips & $\mathrm{n}$. & 2 \\
\hline Touristic supply & $\begin{array}{l}\text { N. of airlines/cruises companies operating at the } \\
\text { airport/river/port }\end{array}$ & n. & 2 \\
\hline Touristic supply & Percentage of fixed assets related to the tourism sector & $\%$ & 1 \\
\hline Touristic supply & N. of hotels/touristic accommodation & $\mathrm{n}$. & 10 \\
\hline Touristic supply & N. of hotel rooms & n. & 3 \\
\hline Touristic supply & N. of hotel beds & $\mathrm{n}$. & 3 \\
\hline Touristic supply & Increase in accommodation capacity & $\%$ & 1 \\
\hline Touristic supply & N. of new travel agencies & $\mathrm{n}$. & 1 \\
\hline Touristic supply & N. of new touristic units & $\mathrm{n}$. & 2 \\
\hline Touristic supply & N. of guided tours & $\mathrm{n}$. & 2 \\
\hline Touristic supply & N. of catering services & $\mathrm{n}$. & 1 \\
\hline
\end{tabular}


Table 3. Cont.

\begin{tabular}{|c|c|c|c|}
\hline & Tourism and Recreation Indicators & & \\
\hline Category & Indicator & Unit of Measure & Frequency Analysis \\
\hline Touristic supply & N. of new restaurants and bars & $\mathrm{n}$. & 3 \\
\hline Touristic supply & Average annual growth in touristic units and rooms & $\%$ & 1 \\
\hline Touristic supply & Percentage of increase in number of guided tours & $\%$ & 1 \\
\hline Touristic supply & Average growth of catering sector & $\%$ & 1 \\
\hline Touristic supply & Average room price & $€ /$ day & 4 \\
\hline Touristic supply & N. of new public underground parking lots & $\mathrm{n}$. & 1 \\
\hline Touristic supply & Admission price in touristic place of interest & $€$ & 1 \\
\hline $\begin{array}{l}\text { Economic impact } \\
\text { on local wealth }\end{array}$ & Contribution of heritage tourism to the city & $€$ & 1 \\
\hline $\begin{array}{l}\text { Economic impact } \\
\text { on local wealth }\end{array}$ & Earnings supported by heritage tourism & $€$ & 1 \\
\hline $\begin{array}{l}\text { Economic impact } \\
\text { on local wealth }\end{array}$ & $\begin{array}{l}\text { Percentage of the contribution of hotels to tourism sector } \\
\text { income/revenues }\end{array}$ & $\%$ & 1 \\
\hline $\begin{array}{l}\text { Economic impact } \\
\text { on local wealth }\end{array}$ & Percentage of fixed assets represented by the tourism sector & $\%$ & 2 \\
\hline $\begin{array}{l}\text { Economic impact } \\
\text { on local wealth }\end{array}$ & Average growth of the touristic sector & $\%$ & 1 \\
\hline $\begin{array}{l}\text { Economic impact } \\
\text { on local wealth }\end{array}$ & Total value of the tourism sector & $€$ & 2 \\
\hline $\begin{array}{l}\text { Economic impact } \\
\text { on local wealth }\end{array}$ & $\begin{array}{l}\text { Percentage of increase in turnover in tourist sector (hotels, } \\
\text { restaurants, bars, tour operators, etc.) }\end{array}$ & $\%$ & 4 \\
\hline $\begin{array}{l}\text { Economic impact } \\
\text { on local wealth }\end{array}$ & Total income generated by the tourism & $€ /$ year & 1 \\
\hline $\begin{array}{l}\text { Economic impact } \\
\text { on local wealth }\end{array}$ & $£$ generated from visits & $€ /$ year & 1 \\
\hline Economic Vitality & N. of licenses in tourism activities & n./year & 2 \\
\hline Economic Vitality & N. of project in tourism promotion & n./year & 1 \\
\hline Economic Vitality & $\begin{array}{l}\text { Additional investment for improving/building new } \\
\text { touristic units }\end{array}$ & $€$ & 2 \\
\hline Economic Vitality & Percentage of hotels' contribution to tourism sector income & $\%$ & 1 \\
\hline Economic Vitality & $\begin{array}{l}\text { Percentage of hotels' contribution to tourism sector total } \\
\text { revenues }\end{array}$ & $\%$ & 1 \\
\hline Economic Vitality & Average lifespan of touristic companies & $\%$ & 1 \\
\hline
\end{tabular}

Table 4. Creative, cultural and innovative activities.

\begin{tabular}{|c|c|c|c|}
\hline \multicolumn{3}{|c|}{ Creative, Cultural And Innovative Activities } & \multirow[b]{2}{*}{$\begin{array}{c}\text { Frequency } \\
\text { Analysis }\end{array}$} \\
\hline Sub-Category & Indicator & Unit of Measure & \\
\hline Cultural demand & $\begin{array}{l}\text { Percentage of visitors stay for temporary } \\
\text { cultural events }\end{array}$ & $\%$ & 1 \\
\hline Cultural demand & N. of visitors for cultural reason & n./year & 14 \\
\hline Cultural demand & N. of participants in cultural events & n./year & 28 \\
\hline Cultural demand & $\begin{array}{l}\text { N. (or percentage) of schoolchildren taking part } \\
\text { in cultural events }\end{array}$ & n./year & 9 \\
\hline Cultural demand & $\begin{array}{l}\text { N. of residents attending or participating in } \\
\text { cultural events }\end{array}$ & n./year & 6 \\
\hline Cultural demand & N. of visitors to cultural attractions/places & n./day & 16 \\
\hline Cultural demand & N. of visitors to the website for cultural reasons & n./day & 1 \\
\hline Cultural demand & N. of projects of cultural programmes & n./year & 24 \\
\hline Cultural demand & N. of tickets sold for cultural events & n. & 3 \\
\hline Cultural demand & N. of people involved in organising events & n. & 1 \\
\hline Cultural supply & $\begin{array}{l}\text { Percentage growth rate of cultural events and } \\
\text { creative activities }\end{array}$ & $\%$ & 2 \\
\hline Cultural supply & N. (or percentage) of cultural events per year & n./year & 19 \\
\hline
\end{tabular}


Table 4. Cont.

\begin{tabular}{|c|c|c|c|}
\hline & Creative, Cultural And Innovative Activities & & \\
\hline Sub-Category & Indicator & Unit of Measure & $\begin{array}{l}\text { Frequency } \\
\text { Analysis }\end{array}$ \\
\hline Cultural supply & $\begin{array}{l}\text { N. (or percentage) of cultural programmes per } \\
\text { year (workshops, exhibitions, etc.) }\end{array}$ & n./year & 5 \\
\hline Cultural supply & N. of cultural institutions & n. & 1 \\
\hline Cultural supply & $\begin{array}{l}\text { N. of cultural facilities/units (archives, } \\
\text { libraries, art galleries, museums, } \\
\text { theatres/cinemas, etc.) }\end{array}$ & n. & 13 \\
\hline Cultural supply & N. of cultural (and creative) enterprises & $\mathrm{n}$. & 2 \\
\hline Cultural supply & N. of new start-ups & n. & 2 \\
\hline Cultural supply & N. artists & n. & 1 \\
\hline Cultural supply & N. of creative and digital firms & $\mathrm{n}$. & 2 \\
\hline Economic vitality & $\begin{array}{l}\text { Attraction of new investments in cultural } \\
\text { heritage and cultural/creative events-activities }\end{array}$ & $€$ & 3 \\
\hline Economic vitality & Average of lifespan of companies & year & 1 \\
\hline $\begin{array}{l}\text { Economic impact } \\
\text { on local wealth }\end{array}$ & $\begin{array}{l}\text { Production in million Euro (total revenues after } \\
\text { VAT) from performing and creative arts }\end{array}$ & $€$ & 1 \\
\hline $\begin{array}{l}\text { Economic impact } \\
\text { on local wealth }\end{array}$ & Value of $(\mathrm{ECoC})$ cultural programmes & $€$ & 7 \\
\hline $\begin{array}{l}\text { Economic impact } \\
\text { on local wealth }\end{array}$ & Advertising value & $€ /$ year & 1 \\
\hline $\begin{array}{l}\text { Economic impact } \\
\text { on local wealth }\end{array}$ & Economic impact generated by cultural events & $€$ & 4 \\
\hline $\begin{array}{l}\text { Economic impact } \\
\text { on local wealth }\end{array}$ & $\begin{array}{l}\text { Direct revenue generated by arts and culture } \\
\text { companies and organizations }\end{array}$ & $€$ & 1 \\
\hline $\begin{array}{l}\text { Economic impact } \\
\text { on local wealth }\end{array}$ & $\begin{array}{l}\text { Sales revenue for arts and culture businesses } \\
\text { and organizations }\end{array}$ & $€$ & 1 \\
\hline $\begin{array}{l}\text { Employment in } \\
\text { cultural activities }\end{array}$ & $\begin{array}{l}\text { N. (or percentage) of artists taking part in } \\
\text { cultural activities }\end{array}$ & n./year & 9 \\
\hline
\end{tabular}

Table 5. Typical local production.

\begin{tabular}{|c|c|c|c|}
\hline & Typical Local Production Indicators & & \\
\hline Sub-Category & Indicator & Unit of Measure & Frequency Analysis \\
\hline $\begin{array}{l}\text { Employment in } \\
\text { local production }\end{array}$ & N. of artisan units & n. & 1 \\
\hline $\begin{array}{l}\text { Employment in } \\
\text { local production }\end{array}$ & N. of craft producers/artisans & n. & 3 \\
\hline Creative firms & $\begin{array}{l}\text { N. (or percentage) of craft stores/new } \\
\text { handcraft shops/small scale } \\
\text { manufacture/local production activities }\end{array}$ & n. & 3 \\
\hline Creative firms & $\begin{array}{l}\text { Percentage of crafts, small scale } \\
\text { manufacture, production activities }\end{array}$ & $\%$ & 1 \\
\hline Local production & $\begin{array}{l}\text { N. of licenses granted in retail and services } \\
\text { for artisan }\end{array}$ & n./year & 1 \\
\hline Local production & $\begin{array}{l}\text { Percentage of wealth of the tourism sector } \\
\text { generated from typical local production } \\
\text { (i.e., food and beverage establishments) }\end{array}$ & $\%$ & 1 \\
\hline Local production & N. of projects in traditional arts & n./year & 1 \\
\hline
\end{tabular}


Table 6. Environment and natural capital.

\begin{tabular}{clcc}
\hline \multicolumn{4}{c}{ Environment And Natural Capital } \\
\hline Sub-Category & \multicolumn{1}{c}{ Indicator } & Unit of Measure & Frequency Analysis \\
\hline $\begin{array}{c}\text { Environmental } \\
\text { preservation }\end{array}$ & $\begin{array}{l}\text { Attraction of new investments } \\
\text { for enhancing of green areas }\end{array}$ & $€$ & 1 \\
\hline $\begin{array}{c}\text { Environmental } \\
\text { preservation }\end{array}$ & $\begin{array}{l}\text { N. of automobiles daily } \\
\text { entered in the historic center }\end{array}$ & n./day & 1 \\
\hline $\begin{array}{c}\text { Green areas and } \\
\text { facilities supply }\end{array}$ & $\begin{array}{l}\text { Percentage of citizens satisfied } \\
\text { of green spaces }\end{array}$ & $\%$ & 1 \\
\hline
\end{tabular}

Table 7. Social capital/cohesion and inclusion.

\begin{tabular}{|c|c|c|c|}
\hline & Social Capital/Cohesion and Inclusion & & \\
\hline Sub-Category & Indicator & Unit of Measure & Frequency Analysis \\
\hline Social cohesion & N. of volunteers & n./year & 19 \\
\hline Social cohesion & N. of volunteer hours & n./hours & 2 \\
\hline Social cohesion & N. of associations & n./10000 inhab. & 3 \\
\hline Social cohesion & N. of social centers/community center & n. & 2 \\
\hline Social cohesion & Percentage (or number) of non-profit organization & $\%$ (or n.) & 3 \\
\hline Social cohesion & N. of events/projects supported by volunteers & n./year & 2 \\
\hline Social cohesion & $\begin{array}{l}\text { New funds to support activities of non-profit } \\
\text { organizations }\end{array}$ & $€ /$ year & 1 \\
\hline Social cohesion & N. of Artisans Registered in the Crafts Association & n. & 1 \\
\hline $\begin{array}{l}\text { Sharing/collaborative } \\
\text { economy initiatives }\end{array}$ & N. of new cooperative enterprises & n./10000 inhab. & 1 \\
\hline Employment & Employment rate/youth employment rate & $\%$ & 2 \\
\hline Employment & Unemployment rate/youth unemployment rate & $\%$ & 1 \\
\hline Employment & N. (or percentage) of workers & n./year & 1 \\
\hline Employment & $\begin{array}{l}\text { N. of people employed in creative } \\
\text { sector/tourism sector }\end{array}$ & n. & 8 \\
\hline Employment & N. of people employed in the third sector & $\mathrm{n}$. & 1 \\
\hline Employment & $\begin{array}{l}\text { N. of people working in the historic center on a } \\
\text { daily basis }\end{array}$ & n./day & 1 \\
\hline Employment & $\begin{array}{l}\text { N. of new jobs (temporary or permanent) (directly } \\
\text { and indirectly) (in hotels, cultural projects, etc.) }\end{array}$ & n. & 15 \\
\hline Employment & N. of jobs in art and cultural occupations & n. & 4 \\
\hline Employment & $\begin{array}{l}\text { N. (or percentage) of jobs related to tourism } \\
\text { economy/heritage tourism, directly and indirectly } \\
\text { (hotels, restaurants, shops) }\end{array}$ & n. $($ or $\%)$ & 16 \\
\hline Employment & $\begin{array}{l}\text { N. of jobs supported by the creativity and } \\
\text { digital sectors }\end{array}$ & n. & 1 \\
\hline Employment & $\begin{array}{l}\text { N. of jobs supported by direct expenditures on } \\
\text { historic preservation }\end{array}$ & & 1 \\
\hline Employment & N. of new businesses & $\mathrm{n}$. & 1 \\
\hline Employment & $\begin{array}{l}\text { Percentage of increase in employment in activities } \\
\text { (or n. of new jobs) related to typical local } \\
\text { production/distribution }\end{array}$ & $\%$ (or n.) & 1 \\
\hline Employment & $\begin{array}{l}\text { Percentage of increase in employment (or n. of new } \\
\text { jobs) within real estate development }\end{array}$ & $\%$ (or n.) & 1 \\
\hline Employment & $\begin{array}{l}\text { N. of employees in supporting institutions } \\
\text { for culture }\end{array}$ & $\mathrm{n}$. & 1 \\
\hline Employment & N. of businesses in historic center & n./year & 1 \\
\hline Social inclusion & Average income & $€ /$ year & 2 \\
\hline Social inclusion & Average monthly salary & $€ /$ month & 4 \\
\hline Social inclusion & $\begin{array}{l}\text { Percentage (or n.) of residents in } \\
\text { low-income households }\end{array}$ & $\%$ (or n.) & 1 \\
\hline
\end{tabular}


Table 8. Real estate.

\begin{tabular}{|c|c|c|c|}
\hline & Real Estate & & \\
\hline Sub-Category & Indicator & Unit of Measure & Frequency Analysis \\
\hline Real estate value & Average price of properties & $€ /$ sqm & 6 \\
\hline Real estate value & Average rent value for residential properties & $€ /$ sqm/month & 40 \\
\hline Real estate value & $\begin{array}{l}\text { Average rent value for commercial-use } \\
\text { properties/offices }\end{array}$ & $€ /$ sqm/month & 2 \\
\hline Real estate value & Average market value for residential properties & $€ /$ sqm & 1 \\
\hline Real estate value & Average market value for commercial-use properties & $€ /$ sqm & 1 \\
\hline Real estate value & $\begin{array}{l}\text { Percentage of increase in private land/properties } \\
\text { value }\end{array}$ & $\%$ & 1 \\
\hline Real estate value & $\begin{array}{l}\text { Percentage of increase in public land/properties } \\
\text { value (due to infrastructure development) }\end{array}$ & $\%$ & 1 \\
\hline Real estate value & $\begin{array}{l}\text { Percentage of increase in value of properties after } \\
\text { historic designation (or within the first year of the } \\
\text { European Capital of Culture announcement) }\end{array}$ & $\%$ & 2 \\
\hline Real estate value & Increase in value of surrounding buildings & $€ /$ sqm $\%$ & 1 \\
\hline Real estate supply & N. (or percentage) of residences/new residences & n. $($ or $\%)$ & 10 \\
\hline Real estate supply & N. (or percentage on the total) of social housing units & n. $($ or $\%)$ & 3 \\
\hline Real estate supply & N. (or percentage) of office spaces & n. (or \%) & 1 \\
\hline Real estate supply & N. (or percentage) of commercial units & n. (or \%) & 3 \\
\hline Real estate development & Volume of transactions in the real estate market & $€$ & 1 \\
\hline Real estate development & Square meters of commercial development & Sqm & 2 \\
\hline Real estate development & N. of new permits related to new constructions & n./year & 7 \\
\hline Real estate development & N. of use change of properties & n./year & 2 \\
\hline Real estate development & N. of new constructions/rehabilitations & n./year & 8 \\
\hline Real estate development & $\begin{array}{l}\text { Percentage (or number) of ownership } \\
\text { houses/commercial units }\end{array}$ & $\%$ & 3 \\
\hline Real estate development & $\begin{array}{l}\text { Percentage (or number) of rented } \\
\text { houses/commercial units }\end{array}$ & $\%$ & 3 \\
\hline Real estate development & Housing/properties vacancy rate & $\%$ & 5 \\
\hline Real estate development & $\begin{array}{l}\text { Percentage of businesses investing in their or } \\
\text { property development }\end{array}$ & $\%$ & 1 \\
\hline Real estate development & Percentage of "building expansion" & $\%$ & 1 \\
\hline Real estate development & Percentage of properties owned by public bodies & $\%$ & 1 \\
\hline Real estate development & Percentage of properties owned by Church & $\%$ & 1 \\
\hline Real estate development & Percentage of privately owned properties & $\%$ & 2 \\
\hline
\end{tabular}

Table 9. Financial return.

\begin{tabular}{|c|c|c|c|}
\hline \multicolumn{4}{|c|}{ Financial Return } \\
\hline Sub-Category & Indicator & Unit of Measure & Frequency Analysis \\
\hline Public financial return & $\begin{array}{l}\text { Increase in taxes related to tourist flows/receipts } \\
\text { from the tourist tax }\end{array}$ & $€ /$ year $\%$ & 1 \\
\hline Public financial return & $\begin{array}{l}\text { Tax revenue from activities in each sector (all } \\
\text { categories-tourism, real estate, etc.) }\end{array}$ & $€$ & 1 \\
\hline Public financial return & $\begin{array}{l}\text { Total local tax revenues supported by direct } \\
\text { expenditures on historic } \\
\text { preservation-investments }\end{array}$ & $€$ & 1 \\
\hline Public financial return & Tax revenues from businesses/sales & $€$ & 2 \\
\hline Public financial return & $\begin{array}{l}\text { Civil insurance to be paid from hotel to be formal } \\
\text { and legal }\end{array}$ & $€ /$ year & 1 \\
\hline Public financial return & $\begin{array}{l}\text { Return to local economy for every } € 1 \text { invested by } \\
\text { the regional authorities }\end{array}$ & $€$ & 1 \\
\hline Public financial return & Earned Revenue due to municipal investments & $€ /$ year & 1 \\
\hline Public financial return & Private Revenue due to municipal investments & $€ /$ year & 1 \\
\hline Public financial return & $\begin{array}{l}\text { Provincial/Federal Investment due to municipal } \\
\text { investments }\end{array}$ & $€ /$ year & 1 \\
\hline
\end{tabular}


Table 10. Cultural value of properties/landscape.

\begin{tabular}{|c|c|c|c|}
\hline \multicolumn{3}{|c|}{ Cultural Value of Properties/Landscape } & \multirow[b]{2}{*}{ Frequency Analysis } \\
\hline Sub-Category & Indicator & Unit of Measure & \\
\hline State of conservation & N. (or percentage) of well-preserved buildings & n. $($ or $\%)$ & 5 \\
\hline State of conservation & N. (or percentage) of buildings in poor condition & n. $($ or $\%)$ & 4 \\
\hline State of conservation & $\begin{array}{l}\text { N. (or percentage) of historic building with } \\
\text { minor problems }\end{array}$ & n. $($ or $\%)$ & 3 \\
\hline State of conservation & N. (or percentage) of buildings in ruin & n. $($ or $\%)$ & 6 \\
\hline State of conservation & N. (or percentage) of improper housing & n. $($ or $\%)$ & 1 \\
\hline State of conservation & Percentage of used/partially used historic building & $\%$ & 2 \\
\hline State of conservation & Percentage of vacant historic building & $\%$ & 1 \\
\hline State of conservation & $\begin{array}{l}\text { N. of historic properties/districts designated to be of } \\
\text { cultural heritage value or interest }\end{array}$ & n. & 1 \\
\hline State of conservation & $\begin{array}{l}\text { N. of restoration and adaptation works undertaken on } \\
\text { historic buildings/sites }\end{array}$ & n./year & 2 \\
\hline State of conservation & Percentage of re-functionalized historic buildings & $\%$ & 1 \\
\hline State of conservation & Area of facades of historic buildings rehabilitated (sqm) & sqm & 1 \\
\hline State of conservation & $\begin{array}{l}\text { Percentage of citizens satisfied with historic } \\
\text { buildings quality }\end{array}$ & $\%$ & 1 \\
\hline State of conservation & $\begin{array}{l}\text { Percentage (or number) of visitors available to make a } \\
\text { contribution to heritage restoration }\end{array}$ & $\%$ (or n.) & 1 \\
\hline State of conservation & $\begin{array}{l}\text { Willingness to pay for a contribution to } \\
\text { heritage restoration }\end{array}$ & $€$ & 1 \\
\hline
\end{tabular}

Table 11. Wellbeing.

\begin{tabular}{|c|c|c|c|}
\hline & Wellbeing & & \\
\hline Sub-Category & Indicator & Unit of Measure & Frequency Analysis \\
\hline Security & $\begin{array}{l}\text { Percentage of citizens feeling safe in the } \\
\text { city/perception of personal safety }\end{array}$ & $\%$ (or Qualitative) & 1 \\
\hline Security & $\begin{array}{l}\text { Average number of crimes (murders, hefts in } \\
\text { dwelling, pickpocketings, robberies) }\end{array}$ & n./100,000 inhab. & 1 \\
\hline Quality of services & $\begin{array}{l}\text { Percentage of citizens satisfied with health } \\
\text { services (and other services) }\end{array}$ & $\%$ & 1 \\
\hline Quality of services & Homes with basic sanitation facilities & n. $\%$ & 1 \\
\hline Quality of services & $\begin{array}{l}\text { Percentage of citizens satisfied with cultural } \\
\text { facilities supply }\end{array}$ & $\%$ & 1 \\
\hline Housing quality & $\begin{array}{l}\text { Percentage of people living in homes without } \\
\text { toilet out of total residents }\end{array}$ & $\%$ & 1 \\
\hline Health & $\begin{array}{l}\text { Percentage of people who lives a cultural } \\
\text { place and reporting good health compared to } \\
\text { those who did not live there }\end{array}$ & $\%$ & 1 \\
\hline
\end{tabular}

Obviously, the matrix is not to be considered as a set of indicators that are efficient overall because the specific conditions of a place, the political preferences, and socio-economic conditions determine the relevance of each specific indicator in the decision-making process.

\section{A Critical Analysis of the Impact Categories}

Before analysing each category, some considerations about the overall indicators framework are necessary.

From the case studies, it is emerged that cultural heritage conservation/valorization is mainly interpreted in touristic and real estate terms. 56 indicators (out of 177) emerged in the touristic category and they are present in all of the case studies (40 out of 40 ).

The most used indicators in the 40 case studies are those that are related to the categories of tourism, real estate, creative, cultural and innovative activities, and social capital/cohesion and inclusion (Figure 1). The indicators of the first two categories frequently recur because the related 
impacts are more immediate and clearer, particularly in the short term. The reason why there are a lot of indicators also related to creative, cultural, and innovative category, is that many of the 40 analyzed case studies have been European Capital of Culture [24]. Furthermore, the indicators related to the social capital/cohesion and inclusion category are mainly referred to the employment sub-category, while the indicators related to the social cohesion are only 8 (out of 28 included in the social capital/cohesion and inclusion category and out of 177 in all 9 categories).

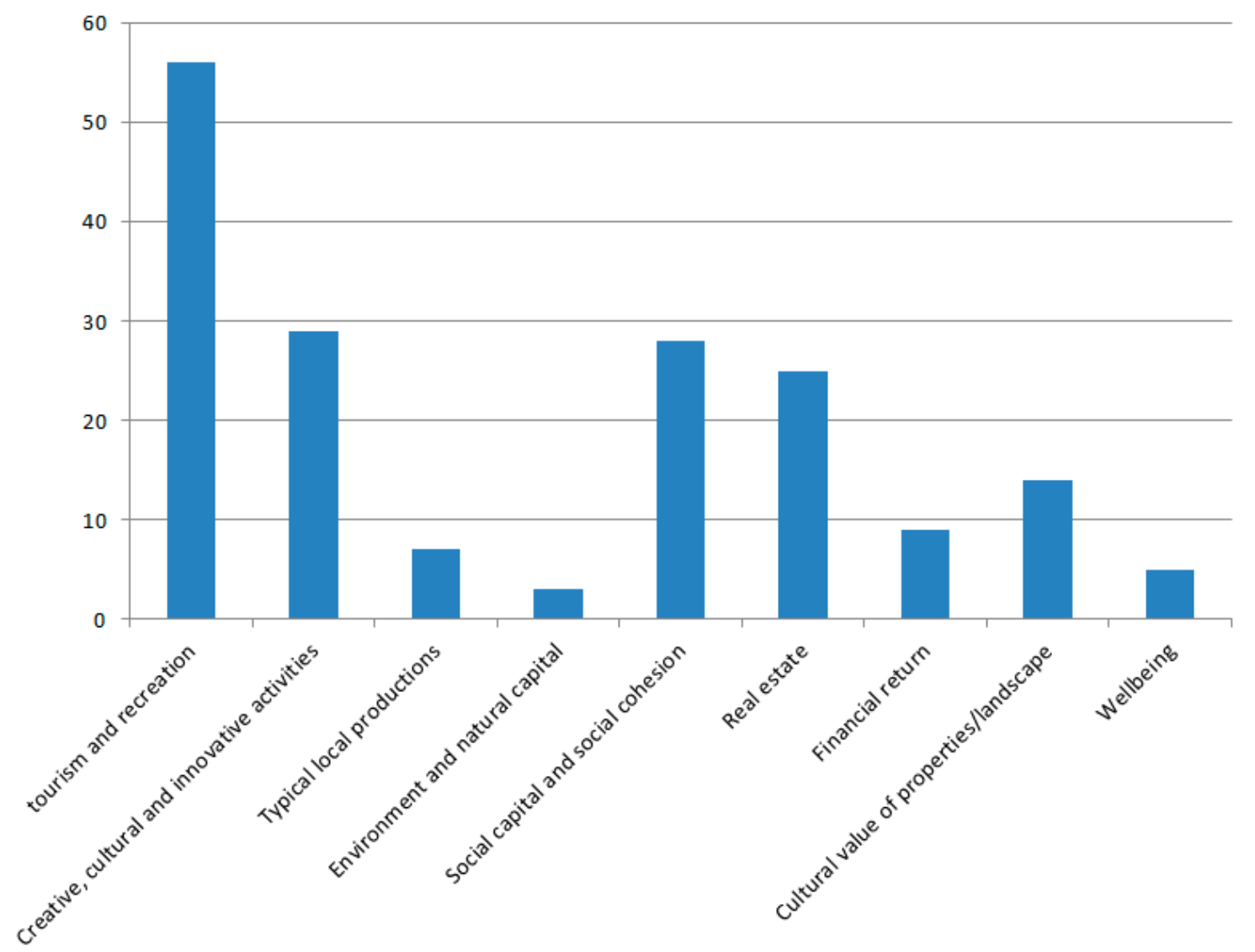

Figure 1. Frequency analysis of indicators of the 40 case studies.

The most frequent indicators in the analysed case studies are those referred to the number of visitors/tourists (emerged from 22 case studies out of 40), number of participants in cultural events (emerged from 28 case studies), the average rent values for residential properties (emerged from 40 case studies) and the number of new jobs (emerged from all case studies).

This is because those indicators are related to aspects for which information are more easily accessible or are related to benefits that are more immediate.

Official data, from which these indicators are mainly extracted, are surely easier to access, but they represent only a part of available data. There are other data, as "big data" [29], that can be very useful to assess dynamic transformation processes. Today, we need to assess in a dynamic way; at the moment data are updated at too much wide periodic intervals and hence they are not so relevant.

The categories whose indicators are less frequent in the case studies are: typical local production, wellbeing and environment, and natural capital. In particular, the indicators of this last category recur only three times ( 3 out of 177), denoting a very lacking awareness about the environmental benefits that cultural heritage conservation/valorization projects are able to produce (they will be analyzed in the following paragraphs). 
In many case studies, some indicators (in particular those related to environmental and natural capital and financial return) are present only at a theoretical level: some analysed reports refer to these indicators, but without quantifying them.

From the analysis of case studies, the inability to understand and evaluate the relationship between variation in wellbeing and variation in the spatial-landscape quality resulting from conservation projects (in terms of wellbeing indicators) emerges.

Moreover, it emerges also the inability to assess variation in the environmental system resulting from changes in the environment itself (in terms of ecological-environmental indicators).

Furthermore, it is interesting to note that no indicators explicitly referred to circular economy (as tool for achieving and implementing sustainable development) emerged from the analysis of case studies, despite the "restorative/regenerative" nature of the circular economy and this concept dates back to the 1960s with K.E. Boulding [30].

This denotes a critical gap between the concept of circular economy (to be interpreted not only related to waste management but to the comprehensive city organization [24,31,32]), and the discipline linked to cultural heritage conservation/valorization. No indicators referring to the concepts of symbiosis and the closing the loops emerge. This demonstrates that there is a wide gap between the model of circular economy that is internationally spreading and its operationalization.

Moreover, not enough attention is focused on the goals of the 2030 Agenda, even though cultural heritage has the potential to contribute (explicitly or implicitly) to the achievement of all of the goals [33]. In fact, the indicators emerged from the case studies mainly referred to the economic dimension, focusing less attention on the benefits that cultural heritage is able to produce in reference to the other two dimensions: social inclusion and environmental protection.

\subsection{Tourism and Recreation Impact Category}

In reference to the analysis of the case studies, the indicators about tourism are the most known because the impacts related to this category are more immediate and clear, especially in the short term [34].

Tourism, defined as "a social, cultural and economic phenomenon related to the movement of people to places outside their usual place of residence, pleasure being the usual motivation" [35], but also for other reasons "such as leisure, business, religious or health reasons and other purposes such as visiting friends and relatives", according to the International Recommendations for Tourism Statistics 2008, has become a pillar of economies, "a passport to prosperity". It is the third largest socio-economic activity in the EU (following the trade and distribution, and construction sectors) [36] and one of the activities that mainly supports the economic sector. Over the years, from 2007 to 2016, the tourism sector has accounted for 9-10\% of GDP, and in 2016, it has supported over 200 million jobs (direct, indirect, and induced impacts) [37]. It employs 1 every 11 people globally [38].

It is a sector that is able to transform cultural values into economic ones. It produces new employment and new wealth in the short time. There are many good practices empirically demonstrating the benefits in tourism sector, in terms of visitors, hotels, restaurants, etc.

Cultural tourism $[39,40]$ can produce many benefits for local communities. It offers a great potential for economic growth and sustainable development but, at the same time, can represent a cost.

Tourism is referred in particular to the instrumental value of cultural heritage, but the latter has also an intrinsic and a social value [20]. All of these values are able to increase (directly or indirectly) the comprehensive city productivity.

Common metrics about impacts on the tourism sector include the number/percentage of visitors, duration of stay, means of transportation, etc. These data are in relation to new jobs opportunities, tax generation, expenditure per day, etc. [41].

The tourism sector alone is no guarantee of the preservation and development of the cultural landscape. The development of tourism in urban areas can have some negative impacts, not only regarding the potential congestion of public spaces and infrastructures, but also regarding inflationary 
processes, both in commercial services (shops, restaurants, or even cultural venues) and in the real estate market. Furthermore, unplanned tourism and unwell managed visitors' access can represent a dangerous threat to the integrity and authenticity of heritage.

The "touristification", that is changes in urban forms and functions due to the growth of tourism [42-45], can pose a threat to the conservation of the values of cultural heritage. Over-utilization of the functional component can cause degradation of the intrinsic value of the heritage, which, consequently, leads to degradation of the use value over time.

If tourism is unwell managed and uncontrolled, it causes degradation of landscape becoming a social, economic, and cultural cost for the community [31]. Since it is configured as the model of the linear economy (take-make-dispose), it can represent the cause of environmental damages. It is the expression of the disposable model.

Tourism development can also be the cause of processes of gentrification, making local residents or users forced to move to peripheral areas of the city. In this sense, it could contribute to increase spatial and social inequalities within the dynamic urban system.

In fact, in some case studies the increase in number of tourists is strictly related to a decrease of residents. Investments should not have as their main goal the increase in number of tourists, but the improvement of residents' living conditions that, in turn, in a circular vision, is a source of tourist attraction: life quality and tourist attractiveness are, therefore, in a symbiotic and circular relationship. As Rypkema states, "if you do it for the locals, the tourists will come; if you do it for the tourists, only the tourists will come" [46,47].

The capacity of tourism to produce wealth in the short term is doubtless but, if direct and indirect costs are considered (considering for example, environmental and socio-cultural negative impacts), they are much less [31].

The impacts emerged from the case studies in the tourism category refer to a "linear tourism" producing benefits in the short time, but negative impacts in the long term. All of the case studies are indifferent to the concept of the "circular tourism" [31], which is able to produce positive impacts both in the short and in the long time.

\subsection{The Double Relationship between Cultural Heritage and Climate Change}

There is a double relationship between the tourism sector and climate change: the tourism sector is contemporaneously both "a vector and a victim" of climate change (UNWTO Secretary-General, Taleb Rifai).

The tourism sector cannot be excluded from the challenge to the global climate change; so, its impacts on climate change (that to date are underestimated) have to be considered, without forgetting the close relationship between tourism and global warming.

Both cultural heritage and cultural tourism are vulnerable to climate change (direct and indirect impacts) [48]; for example, costal tourism, which represents the largest segment of the sector, is affected by sea level rise, beach erosion and others consequents of climate change [48].

Climate change represents a threat to cultural heritage (and consequently to cultural tourism), both to its integrity, authenticity, outstanding universal value (OUV), and to its "enjoyment": climate change effects cultural heritage and consequently has negative impacts on the tourism sector because of the reduction of attractiveness of destinations.

Furthermore, it affects the economies and communities depending on the tourism sector [48].

On the other hand, tourism contributes to about $5 \%$ of global $\mathrm{CO}_{2}$ emissions and it is responsible of $4.6 \%$ of global warming (www.unwto.org).

The accommodation and air transport sectors are the major responsible for the greenhouse gas emissions. The largest amount of emissions in tourism sector is produced by the transport sector (equal to $75 \%$ ).

The accommodation sector accounts for about $20 \%$ of emissions from tourism because of using air-conditioning, heating, etc. [49]. 
Hotels and hotel facilities consume a large amount of non-renewable resources: a resort can consume more water per person than the local community with which it competes for supply. This is because tourism is organized according to the linear model, as opposed to the "circular tourism" that would reuse water and reduce waste.

Tourism is strictly linked to the transport sector and the demand related to tourism sector increases the transport one.

The main tourism contributor to global warming is the air travel; in fact, it is responsible for $40 \%$ of the total carbon emissions caused by tourism, and $54-75 \%$ of radiative forcing.

Although the majority tourists travel by car, air transports and cruises are mainly responsible for greenhouse gas emissions associated to tourism sector, even when considering that most cruise trips start with a flight to the place of departure and cruising is the mean of transportation producing more amounts of greenhouse gas emissions per kilometer travelled.

According to an ICAO study, the pollution produced by a person travelling by plane on a long-distance equals that produced by a motorcycle in two months; additionally, the pollution generated by an intercontinental air travel from Paris to New York (one way trip) equals that produced by the energy consumed in a house in ten days $\left(38,158 \mathrm{~kg}\right.$ of $\left.\mathrm{CO}_{2}\right)$ (www.icao.int).

The need for alternative fuels has been recently discussed and some actions have already been taken.

For example, the Committee on Aviation Environmental Protection of the International Civil Aviation Authority in 2016 has provided a recommendation for $\mathrm{CO}_{2}$ emissions standard for aircraft (ICAO 2016 da UNEP et al.).

Considerable steps forward have been made in increasing fuel efficiency. Nevertheless, aircrafts cannot use the currently available biofuels because, to date, they do not remain in a liquid state at low temperatures, as required from the fuel to be used by aircraft [49].

Further actions about air traffic management (as to fly at optimal altitudes and speeds and to reduce time spent waiting to land), technology, green businesses, and monitoring should be implemented to reduce the negative environmental impacts due to the ever-increasing demand.

\subsection{Environment and Natural Capital Impact Category}

Although the negative impacts (related to the double relationship between cultural heritage/cultural tourism and climate change) highlighted in the previous paragraph, the integrated conservation is able to produce also environmental benefits. The indicators related to this category rarely emerge from the analysis of the case studies: only three indicators (out of 177 referred to the 9 categories) in three case studies out of forty. Some case studies deal with environmental benefits only at the theoretical level.

It denotes a lacking of awareness about the real benefits that the investments in cultural-led projects are able to produce for the environmental system (as the contribution of the circular economy suggests). It is worrying, as in the era of international sustainable development and circular economy, the ecological dimension is so poorly considered.

Many of benefits related to this category are indirect, so they are expressed in terms of "avoided costs" (reduction of energy consumption, waste reduction, etc.). The reduction of costs related, for example, to natural hazards disaster can represent a significant indicator in this category.

Therefore, economic indicators related to this category can be expressed as money saved, rather than money gained as for the other categories (i.e., property values, earning).

Environmental benefits can be also referred to as measurements of land saving use due to building reuse (rather than demolished) and the reduction in $\mathrm{CO}_{2}$ emissions thanks to restoration of a building rather than rebuilding it. Indicators about pollution reduction produced by cultural-led projects, such as the amount of raw materials- water savings, should be identified. 
A report about investments in Maryland highlights that 387,000 tons of material from landfills have been saved investing in historic properties over the past 12 years ("this amount of landfill material is the equivalent of filling a football stadium to a depth of 50-60 feet") [50].

The World Bank recognized the investments in cultural heritage as a good solution to reduce the $\mathrm{CO}_{2}$ emission and climate change because activities related to cultural heritage represent an intrinsically more sustainable model of land use, consumption, and production that has been developed over the time through a continuous adaptation between communities and their environment [51]. Thereby, cultural heritage can help to face climate change challenge for example "through the protection and revitalisation of the huge embedded energy in the historic building stock" [28].

\subsection{Cultural Value of Properties/Landscape and Social Capital/Cohesion and Inclusion Impacts Categories}

As mentioned above, climate change can have negative impacts on integrity and authenticity of cultural heritage, damaging, and depriving the community of its "symbols". This is both physical and intangible deprivation. This draws also the attention to issues related to the enhancement of the local community, in addition to tourism and real estate issues.

In this perspective, indicators related to the state of conservation of cultural heritage and the enhancement of local community (social cohesion and civic conscience) have to be considered.

Cultural heritage is integral part of life of communities and it is involved in social, economic, and environmental processes. It is expression of culture, identity, and religious beliefs of societies.

If we are able to conserve cultural heritage, we construct memory of ourselves and therefore we are able to conserve identity in the current globalization changes. Conservation expresses the deliberate effort to fix the memory in time to avoid losing our identity.

We can react to the risk of losing our identity (as a result of globalization) through cultural heritage and, at the same time, we fix the memory through cultural heritage that has been handed down passing it, in turn, on the future generations.

Cultural heritage expresses and maintains values and traditions of a city and its community, but its significance can be different among communities and also among members of the same community. It links past, present, and future but, at the same time, it has the potential for conflicts.

Diverse social groups could have different values and beliefs, with different perceptions about what is relevant for their identity, attributing different values to a heritage place.

The coexistence of these differences can represent a problematic issue and sometimes can be the cause of actions that could have negative impacts on heritage values.

Conflicts and disagreements (in terms of values, interests, beliefs) can represent, if it is not well managed, an obstacle in the achievement of heritage outcomes to produce benefits to each involved stakeholder. Differences are inevitable, but they need to be acknowledged and respected in order to mitigate the possible conflicts. A fundamental step of heritage management is to understand heritage values held by different groups within a society.

Today, the increasingly multicultural society requires reciprocity and dialogue. Cultural heritage becomes a source of identity representing an entry point for cultural dialogue, mutual knowing, and comparison.

Cultural heritage is subject to continuous changes, continuous hybridization processes to adapt itself throughout history [52]: each building expresses the "graft" of new points of view, new styles, etc. in the historical tradition [53]. It represents an "ingredient" for putting end to conflicts through a mutual knowledge of values. Therefore, cultural heritage plays a key role in promoting a more peaceful coexistence.

A place that keeps its historical and cultural asset/values intact as much as possible is able to attract at the same time the permanence of the resident population, to strengthen the sense of belonging of citizens, to increase civic and individual attention to safeguarding. It is also able to trigger virtuous mechanisms for attracting tourist flows that feed the overall economic well-being.

In this perspective, indicators about the state of conservation of landscape values are fundamental. 
The preservation of the diversity of cultural heritage, and also an equitable access to it and a fair sharing of benefits related to it, enhance the sense of belonging; the capacity to maintain the common good contributes to social cohesion reducing, at the same time, inequalities. Therefore, the social issue plays a fundamental role in the cultural heritage conservation/regeneration.

Cultural heritage is able to build social capital and to contribute to social cohesion providing a framework for participation and engagement, and also for fostering integration [14,28,54-58].

It is fundamental for community/social cohesion as it expresses values and identity and organizes communities and their relationships through its powerful symbolic and aesthetic dimensions. Cooperative and collaborative relationships improve the quality of life and make landscape more attractive.

Cultural heritage has positive impacts on social capital, revitalizing synergies, bonds, and collaborative relationships. It is able to encourage associations, crowdfunding projects, etc. that contribute to local economic productivity. New forms of economy (crowdfunding, municipal bonds, etc.) should support the traditional one.

Employment is a key word related to social capital; it is a very significant indicator of social inclusion. It is a significant social indicator that contributes to make people "feel good", not only because of economic aspects, but because it let people be in relationship each other's. Projects should aim to improve human life conditions and, in this perspective, economics and technologies have to represent a mean (and not a goal).

While there are a lot of indicators about employment sub-category (emerged at almost all case studies), there is still a lack of evidence about the contribution of cultural heritage to social cohesion.

Indicators related to the number of crowdfunding projects, the number of participants in crowdfunding initiatives, amount of donations for cultural heritage, and municipal bonds/crowdfunding incomes for heritage projects can be significant indicators for giving empirical evidence about the social cohesion benefits produced by cultural heritage.

\subsection{Typical Local Productions Impact Category}

Local production (craft and traditional products), as part of cultural heritage, is able to enhance local identity, too. Local specialties, representing local identity, are able to impart values of the community: identity values of the territory are expressed also through typical local products, when considering the strong link between the product and its place of origin.

Companies, in particular smaller size ones, see in the typical products a chance to find a new competitive space against increasingly competitive markets by price. Despite that they usually are small size, firms that locally sell typical local products may boost economic growth in the city.

At the same time, local governments are interested in local production, seeing it as a means to strengthen identity and social cohesion, stimulating synergies and bonds.

Through the enhancement of typical local products, merely productive function is integrated with other functions, including environmental safeguard and the conservation of culture, producing, at the same time, spaces/places of economic and social dynamics [59].

Local resources can be tangible or intangible magnets for touristic flows. They can be the engine of local economy (also attracting visitors) and, at the same time, an expression of local culture. Local production places oneself as a cog in the tourist sector.

Typical local production, for example, craft products or gastronomy, can be a motivational and promoter factor of business in the territory. This means that a typical food product can convey demand for tourism and animate holidays, becoming feed for local economy. Gastronomic experience is both a mean of knowledge of the city and a link between the production chain and tourism industry, thanks to the generation of relationships/synergies among operators: producers, typical shops, accommodation and recreation activities, tour operators, etc.

The typical products, closely linked to local specificities, represent a point of contact between the authenticity of a territory and the tourists. 
Therefore, the typical products, as a form of expression of local culture, have impacts on social and economic development of a territory, producing benefits such as increasing in income of small producers, enhancing identity, increasing in social vitality, regeneration of traditional activities, new jobs, etc.

A few number of indicators emerge from the case studies in relation to this category: only seven indicators (out of 177 referred to the 9 categories) are related to typical local production.

Some indicators related to local production, as the selling price of traditional products, annual growth rate of traditional production, net present value of economic activity, and internal profit rate of economic activity can be significant for highlighting the benefits produced in this category.

Furthermore, in a circular perspective, the attention is focused on the production and distribution chain. The implementation of circular economy model in the local production chain implies to close the loops, contributing to achieve sustainable development by reducing negative impacts on the environmental system and improving, at the same time, the economic dimension. In fact, starting from geography proximity, closing the loops allows for reducing waste, energy consumption, etc. Therefore, further indicators related to the circular economy implementation in the local production and distribution chain are necessary.

\subsection{Real Estate and Financial Returns Impact Categories}

As for tourism category, also the indicators related to the real estate category are more known because the related impacts are more immediate and clearer, especially in the short term.

Real estate is positively influenced by investments in cultural heritage: the project areas and the surrounding areas usually revealed an increase in real estate value.

Sometimes this increase can have negative impacts, such as gentrification phenomenon (interpreted as expulsion of the most vulnerable part of the population both in economic terms and cultural ones): local community and young people can no longer afford to buy/rent apartments because of rising prices; therefore, as has emerged from some case studies, many apartments remain unused for many years and the owners do not care about maintenance, causing the deterioration of them.

Furthermore, the increase in property value produces a "touch and go" tourism because of the high prices to stay in the area object of intervention.

The gentrification processes could contribute, as above mentioned, to increase spatial and social inequalities within the dynamic urban system. Modifying social composition allows for redistributing economic benefits coming by having richer inhabitants that, having more money to spend, can contribute to revitalize the economy of the neighborhood. But, in this way, the problem of poverty, and more in general social issues, is simply moved outside. It is the consequent of actions that take into account only economic attractiveness. Instead, social and cultural components need to be considered in regeneration strategies/policies in order to limit negative impacts.

The analysed case studies show that continuing to use the buildings is an effective strategy to prevent their deterioration. While respecting its identity, but maximizing the economic potential of adaptive reuse, "keeping alive" a historical building is an effective strategy to protect it.

Furthermore, in the re-use/regeneration of historic buildings lies a huge economic potential in terms of employment (relation with the social capital category).

In built environment there is a great potential for saving energy. The investments can pay back well during life cycle of the goods. Energy saving can be achieved through investments in technologies (such as renewable energy systems, energy efficient lighting, cooling, heating), but also through territorial management and behavioral and lifestyle changes.

Furthermore, historical buildings can contribute to face climate change thanks to its wise features. An effective orientation and the physical characteristics, for example, the walling's gauge, contribute to guarantee a lesser temperature inside and outside the buildings, improving the general microclimatic condition. 
The real estate benefits are direct benefits for owners and, at the same time, they turn into tax revenue for public bodies.

In fact, investments in cultural heritage are able to generate financial returns, stimulating real economic growth. They are able to generate tax revenue for public authorities, both directly and indirectly [28].

The direct one is referred to heritage-related activities; the indirect one is related to spillover from heritage-related projects/programs leading to further investments.

Public financial benefits can be expressed in terms of increasing in taxes due:

- to commercial/residential development and tourist flow (receipts from tourist tax, increase in taxes related to real estate taxes, property taxes gained from commercial development, etc.);

- to the avoided expenditure for management and maintenance of cultural heritage due to increasing in private investments; and,

- $\quad$ to new activities and businesses started up thanks to cultural heritage regeneration.

A significant economic indicator of investment in cultural heritage is the return on investment, both for public bodies and for private investors.

Only nine indicators have been emerged from case studies in the category about financial return and are mainly related to tax revenues from activities in different sectors.

\subsection{Wellbeing Impact Category}

Mere economic indicators, as those referred to in the above-mentioned financial category, leave out many aspects that are not economically evaluable. They are able to evaluate the economic growth, but they do not represent people wellbeing. They alone are not significant because they are not able to capture information about wellbeing, happiness and the level of the life quality of citizens: it needs to go beyond the mere economic numbers.

Economics should be only instrumental to the achievement of wellbeing. Thereby, "the mere economic numbers" need to be put necessarily in relation to other indicators, able to capture the multidimensional impacts of the integrated conservation.

In a period characterized by a considerable unsustainability, the evaluation of wellbeing assumes a central role, as underlined from the Rio +20 Conference that focused the attention on a new paradigm that goes beyond environmental improvement, promoting also social and economic well-being [2].

When considering cultural heritage as a common good, any activity, aiming at preserving or valorizing it, is able to produce benefits for the community in which it places. Therefore, tools for assessing the impacts of cultural heritage conservation/valorization on community wellbeing are necessary.

Data demonstrate that "engaging with culture (visiting, attending and participation) significantly increases overall life satisfaction" [56].

Wellbeing is not related only to the economic wealth, but also to the condition able to ensure social cohesion, human rights fulfilment, human needs fulfillment, etc.

Wellbeing is a multidimensional concept that changes in the spatial and temporal dimension. It changes in time, place, and culture.

Despite of the health dimension, principally associated to the medicine and having always the same parameters, in order to define the wellbeing dimension, it is important to understand the context in which people live.

In the common belief that wellbeing is associated with a good quality of life, it is a true assumption, but quality of life is not the only indicator of wellbeing. It is associated to a comfortable, healthy, happy life and life quality affects this state. Life satisfaction is another of the different indicators used (in combination with others) to assess the wellbeing. 
Wellbeing indicators are used to measure people's general satisfaction with life and to give information about quality of life with reference to jobs, family life, health conditions, and standards of living.

They are also related to safety perception. This indicator is fundamental in a regeneration process because it is not related to the regeneration of space, but it is related to human landscape. Thereby, this indicator assumes a strong significance.

Cultural heritage contributes to bettering urban life in different ways, for example, providing options for housing (through reuse), to improve public spaces, etc.

There is no much empirical evidence about the contribution of cultural heritage to the achievement of wellbeing. The contribution of cultural heritage to wellbeing is poorly considered. This statement is supported by the analyses of case studies from which only seven indicators (out of 177 referred to the 9 categories) emerge in this category.

\section{Discussion}

This study has highlighted that cultural heritage conservation/valorization is mainly interpreted in touristic and real estate impacts; in fact, these impact categories have a great number of indicators (56 indicators for tourism category and 25 for the real estate one both out of 177).

It is important to understand not only how much development is produced in reference to each category, but how much this development is sustainable (for example, the increase in number of tourists is not necessarily a benefit, especially if not well managed).

In fact, as underlined in the 4.2 paragraph, the net benefits produced by tourism can be much less if we consider costs, both direct and indirect ones (considering, for example, the environmental and socio-cultural negative impacts).

Tourism promotion is sustainable to the extent that it produces not only economic impacts, but contributes also to community wellbeing.

Furthermore, the environmental costs are today underestimated and the relationship between the tourism sector and climate change is not considered enough.

There is a double relationship between tourism sector and climate change. From one hand, climate change represents a threat to cultural heritage, and consequently for cultural tourism (for example reducing attractiveness of places); on the other hand, tourism considerably contributes to the global $\mathrm{CO}_{2}$ emissions and global warming.

New tourism management strategies are necessary to reduce these costs (environmental, socio-cultural, and economic ones) and, simultaneously, produce more benefits.

Although there are some academic researches about the relationship between the tourism sector and climate change, insufficient actions are undertaken (for example by tour operators) because there is not so much empirical research in this regard to justify actions and adaptation.

To date, there is no a "science-based assessment of climate impacts and vulnerability at all World Heritage sites" [48] and, vice versa, assessment of impacts of cultural heritage conservation/regeneration on climate change.

Lack of resources (financing, capacity building, etc.) represents a great obstacle for the effective management of cultural heritage, including the assessment of sensitivity to climate change and the planning of sustainable tourism.

It needs to adopt measures that are able to reduce the negative impacts of uncontrolled/unsustainable tourism and climate change on cultural heritage and, vice versa, reduce the impacts of cultural tourism (but also tourism in general) on climate change.

Some international documents about this issue already exist, as the document on the Impacts of Climate Change on World Heritage Properties [60], but more additional measures are needed.

Furthermore, the set of indicators about the tourism category (emerged from the case studies) are referred to as "linear tourism" and are indifferent to the concept of the "circular tourism" [31], which is able to produce positive impacts both in the short and in the long time. In this framework, 
the indicators related to tourism should be integrated with indicators related to climate-changing emissions and circular tourism.

Moreover, it is important to underline that the benefits produced by cultural heritage conservation/regeneration do not end in the tourism or real estate sectors but, as emerged from the analysis of the case studies, they are multidimensional benefits, from economy to ecology, to culture, to social needs, to wellbeing.

In a period in which sustainable development and circular economy (as the process towards sustainability) are the core topic of many international debates and researches, the indicators related to wellbeing are absolutely necessary.

Although wellbeing represents a fundamental dimension to express the nature of sustainability [2] and can be recognized as the ultimate goal of sustainable development, it rarely emerges from the case studies. In fact, only seven indicators (out of 177 referred to the 9 categories) are present in this category.

It confirms that, although wellbeing is increasingly assuming a central role in this period characterized by a considerable unsustainability, its evaluation is very still lacking.

The promotion of wellbeing (of residents and tourists) should go beyond the economic wealth and should be related also to the condition able to ensure social cohesion, human rights, and needs fulfilment, etc.

More indicators and empirical evidence are necessary to evaluate the wellbeing dimension and, in particular, to assess and demonstrate the relationship between variation in wellbeing and variation in the spatial-landscape quality resulting from conservation projects.

The indicators proposed by the Italian National Institute of Statistics (ISTAT) in the Equitable and Sustainable Wellbeing (BES) Report [61] can represent a step forward. In this report the factors (economic, social and environmental factors) contributing to the quality of life are identified and analysed. Among the identified 12 dimensions (and 130 indicators) of wellbeing, there is one of them explicitly referred to landscape and cultural heritage.

It can be considered an effective tool to promote wellbeing aiming at the integration of "traditional economic indicators" with indicators related to the quality of life that consider equity and sustainability issues able to give a more complete point of view about the society development.

Furthermore, no indicators explicitly referred to the circular economy (as a tool for achieving and implementing sustainable development) emerge from the present study.

The circular economy has intrinsically a "restorative/regenerative" nature, so it should be strictly linked to the conservation/regeneration of use value. This concept includes the social and environmental components, which were very lacking in the analysed case studies. The substantial absence of explicit indicators referred to circular economy shows the wide gap between the model of circular economy and it operationalization.

Nevertheless, there are some indicators that can be considered referred to the capacity of the circular economy to the indefinite enlargement of the lifetime of resources.

The circular economy allows for conserving the use-value of heritage, through the regeneration of resources, and the intrinsic one. It allows for conserving "alive" a symbol of community identity (cultural benefits), increasing economic productivity (economic benefits), reducing of resource consumption (environmental benefits), and producing social benefits (i.e., employment).

In the analysed case studies, the structural aspect that is common both to the re-functionalization and to the circular economy model, namely the regeneration of the use value over time, is not taken into account. There is no awareness about this assonance that would be made explicit through a set of indicators integrating those identified.

So, maintenance, reuse, restoration, rehabilitation, but also valorization and regeneration are key words and they are improved through circular processes.

In this sense, some indicators, such as the number of restoration and adaptation works undertaken on historic buildings/sites, the percentage of re-functionalized historic buildings, and the area 
of facades of historic buildings rehabilitated (sqm) could be interpreted in the circular economy perspective, by extending the lifetime of resources over time.

It is emerged also a lack of evidence about the contribution of cultural heritage to social cohesion (only 8 indicators out of 177 emerge from case studies). It needs more indicators that are able to assess the "glue" value of cultural heritage in social cohesion terms. Some case studies deal with these benefits only at theoretical level, without quantifying them.

The benefits about the environmental category are very poorly considered (only three indicators from 40 case studies). It denotes a lacking of awareness about the real benefits that the investments in cultural-led projects are able to produce for the environmental system, as the contribution of the circular economy suggests.

\section{Conclusions}

The analysis of the 40 case studies has aimed at the extraction of the indicators assessing the multidimensional benefits that cultural heritage conservation/regeneration is able to produce.

Although the analyses often refer to sustainability, it is not concretely addressed because there is an imbalance among the dimensions: in most cases, only the economic component is highlighted, leaving out the social and environmental dimensions.

As mentioned above, the impacts related to cultural-led projects are mainly interpreted in terms of tourism and real estate impacts. In the perspective of sustainable development, it is necessary to consider a "circular tourism" able to produce positive impacts both in the short and in the long time (unlike the linear tourism emerging from case studies). Furthermore, it is important to underline that the benefits from cultural heritage conservation/regeneration do not end in the tourism impacts but, as emerged from the analysis of case studies, they are multidimensional benefits (economic, social, environmental, etc. benefits). This calls for an adequate set of indicators to integrate the indicators matrix deduced from the analysis of case studies and are able to consider the above mentioned issues to date not included in projects/programmes evaluations.

In conclusion, tools to evaluate the contribution of cultural heritage to the achievement of sustainable development (considering the multidimensional benefits that it is able to produce) and the identification of new effective model for sustainable management of cultural heritage are necessary. Open fields for future research are thus related to the development of tools for evaluating the role of cultural heritage (and cultural tourism) in the climate change challenge and the relationship between cultural heritage and wellbeing and social cohesion categories.

Indicators and evaluation methods to assess the contribution of cultural heritage to increase city multidimensional productivity still represent a gap and thus an open field of experimentation. These indicators should be referred also to the concept of circular economy that, stressing the importance of closing loops, represents a model that is able to make not only the traditional economy more efficient and productive, but also to stimulate cooperation, collaboration, and synergies.

Conflicts of Interest: The author declares no conflict of interest.

\section{References}

1. United Nations. Our Common Future: Report of the World Commission on Environment and Development_-Brundtland Report; United Nations: New York, NY, USA, 1987.

2. United Nations. The future we want: Final document of the Rio+20 Conference. In Proceedings of the Rio20 United Nations Conference Sustainable Development, Rio de Janeiro, Brazil, 20-22 June 2012.

3. United Nations. Transforming our World: The 2030 Agenda for Sustainable Development; United Nations: New York, NY, USA, 2015.

4. United Nations. United Nations Millennium Declaration; United Nations: New York, NY, USA, 2000.

5. UN-Habitat. Report of the United Nations Conference on Human Settlements (Habitat II), Istanbul, 3-14 June 1996; United Nations: New York, NY, USA, 1996. 
6. United Nations. Adoption of the Paris Agreement. In Proceedings of the Conference of the Parties Twenty-First Session Paris, Paris, France, 30 November-11 December 2015.

7. United Nations. Marrakech Action Proclamation for Our Climate and Sustainable Development; United Nations: New York, NY, USA, 2016.

8. Ellen MacArthur Foundation. Growth within: A Circular Economy Vision for a Competitive Europe; Ellen MacArthur Foundation: Cowes, UK, 2015.

9. European Commission. Communication from the Commission to the European Parliament, the Council, the European Economic and Social Committee and the Committee of the Regions. Towards an Integrated Approach to Cultural Heritage for Europe. Brussels, 22.7.2014; European Commission: Brussels, Belgium, 2014.

10. Braungart, M.; McDonough, M. Cradle-to-Cradle; Remaking the Way we Make Things; North Point Press: New York, NY, USA, 2008.

11. Preston, F. A Global Redesign? Shaping the Circular Economy; Chatham House Briefing Paper, EERG BP 2012/02; Chatham House: London, UK, 2012.

12. Fusco Girard, L.; Cerreta, M.; De Toro, P. Towards a Local Comprehensive Productive Development Strategy: A Methodological Proposal for the Metropolitan City of Naples. Qual. Innov. Prosper. 2017, 21, 223. [CrossRef]

13. United Nations. Draft Outcome Document of the United Nations Conference on Housing and Sustainable Urban Development (Habitat III); United Nations: New York, NY, USA, 2016.

14. Hosagrahar, J.; Soule, J.; Fusco Girard, L.; Potts, A. Cultural Heritage, the UN Sustainable Development Goals, and the New Urban Agenda. Available online: http:/ /www.usicomos.org/wp-content/uploads / 2016/05/Final-Concept-Note.pdf (accessed on 12 October 2017).

15. Potts, A. The Position of Cultural Heritage in the New Urban Agenda a Preliminary Analysis Prepared for ICOMOS; ICOMOS: Charenton-le-Pont, France, 2016.

16. Throsby, D. Culture in sustainable development: Insights for the future implementation of art. 13. In Convention on the Protection and Promotion of the Diversity of Cultural Expressions; UNESCO: Sydney, Australia, 2008.

17. Srakar, A.; Vecco, M. Culture as a Fourth Dimension of Sustainable Development? A Statistical Analysis. 2016. Available online: http:/ / eventos.uva.es/file_manager/get_paper/3421 (accessed on 12 October 2017).

18. UNESCO. Recommendation on the Historic Urban Landscape; UNESCO World Heritage Centre: Paris, France, 2011.

19. Fusco Girard, L.; Gravagnuolo, A.; Nocca, F.; Angrisano, M.; Bosone, M. Towards an economic impact assessment framework for Historic Urban Landscape conservation and regeneration projects. BDC. Boll. Cent. Calza Bini 2015, 15, 1-29.

20. Fusco Girard, L. Risorse Architettoniche e Culturali: Valutazioni e Strategie di Conservazione; Franco Angeli: Milano, Italy, 1987.

21. Fusco Girard, L.; Nijkamp, P. Le Valutazioni per lo Sviluppo Sostenibile Della Città e Del Territorio; Franco Angeli: Milano, Italy, 1997.

22. Fusco Girard, L. The role of cultural urban landscape towards a new urban economics: New structural assets for increasing economic productivity through hybrid processes. Hous. Policies Urban Econ. 2014, 1, 3-27.

23. Fusco Girard, L. Toward a Smart Sustainable Development of Port Cities/Areas: The Role of the Historic Urban Landscape Approach. Sustainability 2013, 5, 4329-4348. [CrossRef]

24. Nocca, F. Hybrid Evaluation Tools for Operationalizing Unesco Historic Urban Landscape Approach; University of Naples Federico II: Naples, Italy, 2017.

25. Ost, C. Mapping Heritage Economics for Spatial Analysis in Historic City Cores. In The Economics of Uniqueness. Investing in Historic City Cores and Cultural Heritage Assets for Sustainable Development; Licciard, G., Amirtahmasebi, R., Eds.; World Bank Group: Washington, DC, USA, 2012; pp. 245-283.

26. Munarim, U.; Ghisi, E. Environmental feasibility of heritage buildings rehabilitation. Renew. Sustain. Energy Rev. 2016, 58, 235-249. [CrossRef]

27. Tweed, C.; Sutherland, M. Built cultural heritage and sustainable urban development. Landsc. Urban Plan. 2007, 83, 62-69. [CrossRef]

28. CHCfE Consortium. Cultural Heritage Counts for Europe; CHCfE Consortium: Krakow, Poland, 2015.

29. Steenbruggen, J.; Kourtit, K.; Nijkamp, P. The significance of digital data systems for smart city policy. Socioecon. Plan. Sci. 2016, 58, 13-21. [CrossRef] 
30. Boulding, K.E. The economics of the Coming Spaceship Earth. In Environmental Quality Issues in a Growing Economy; Henry, J., Ed.; Johns Hopkins Press: Baltimore, MD, USA, 1966; pp. 3-14. ISBN 9781315064147.

31. Fusco Girard, L.; Nocca, F. From linear to circular tourism. Aestimum 2017, 51-74. [CrossRef]

32. Angrisano, M.; Biancamano, P.F.; Bosone, M.; Carone, P.; Daldanise, G.; De Rosa, F.; Franciosa, A.; Gravagnuolo, A.; Iodice, S.; Nocca, F.; et al. Towards operationalizing UNESCO Recommendations on "Historic Urban Landscape": A position paper. Aestimum 2016, 165-210. [CrossRef]

33. Committee on Culture of the World Association of United Cities and Local Governments (UCLG). Culture in the Sustainable Development Goals: A Guide for Local Action; UCLG: Barcelona, Spain, 2017.

34. D'Auria, A. Urban cultural tourism: Creative approaches for heritage-based sustainable development. Int. J. Sustain. Dev. 2009, 12, 275-289. [CrossRef]

35. United Nations World Tourism Organization (UNWTO). International Recommendations for Tourism Statistics 2008; United Nations World Tourism Organization: Madrid, Spain, 2010.

36. Juul, M. Tourism and the European Union-Recent Trends and Policy Developments. European Parliament, 2015. Available online: http:/ / www.europarl.europa.eu/thinktank/en/document.html?reference=EPRS_ IDA(2015)568343 (accessed on 12 October 2017).

37. United Nations World Tourism Organization (UNWTO). Tourism Highlights, 2016th ed.; United Nations World Tourism Organization: Madrid, Spain, 2016.

38. World Travel and Tourism Council (WTTC). Travel \& Tourism: Economic Impact 2017 World; World Travel and Tourism Council: London, UK, 2017.

39. ICOMOS. Charter of Cultural Tourism; ICOMOS: Charenton-le-Pont, France, 1976.

40. ICOMOS. International Cultural Tourism Charter. Managing Tourism at Places of Heritage Significance; ICOMOS: Charenton-le-Pont, France, 1999.

41. Rypkema, D.; Cheong, C. Measurements and Indicators of Heritage as Development. In Proceedings of the ICOMOS 17th General Assembly, Paris, France, 27 November-2 December 2011; pp. 755-762.

42. García-Hernández, M.; de la Calle-Vaquero, M.; Yubero, C. Cultural heritage and urban tourism: Historic city centres under pressure. Sustainability 2017, 9, 1346. [CrossRef]

43. Jansen-Verbeke, M. The Territoriality Paradigm in Cultural Tourism. Tourism 2009, 19, 25-31. [CrossRef]

44. Ashworth, G.J.; Tunbridge, J.E. The Tourist-Historic City; Belhaven Press: London, UK, 1990.

45. Glasson, J. Oxford: A heritage city under pressure: Visitors, impacts and management responses. Tour. Manag. 1994, 15, 137-144. [CrossRef]

46. Rypkema, D. The Economics of Historic Preservation: A Community Leader's Guide; National Trust for Historic Preservation: Washington, DC, USA, 2003.

47. Rypkema, D. Preservation: More than Bricks and Mortar. In Proceedings of the Kansas Main Street Conference, Hutchinson, KS, USA, 20 February 2010.

48. Markham, A.; Osipova, E.; Lafrenz Samuels, K.; Caldas, A. World Heritage and Tourism in a Changing Climate; United Nations Environment Programme: Nairobi, Kenya; United Nations Educational, Scientific and Cultural Organization: Paris, France, 2016.

49. United Nation World Tourism Organization (UNTWO); United Nations Environment Programme (UNEP). Climate Change and Tourism Responding to Global Challenges; World Tourism Organization: Madrid, Spain, 2008; ISBN 9789284412341.

50. Cronyn, J.; Paull, E. Heritage Tax Credits: Maryland's Own Stimulus to Renovate Buildings for Productive Use and Create Jobs, an \$8.53 Return on Every Dollar Invested. Abell Rep. 2009, 22, 2-9.

51. Hassan, N. Al Introducing Cultural Heritage into the Sustainable Development Agenda. In Proceedings of the Hangzhou International Congress, Hangzhou, China, 15-17 May 2013; pp. 1-5.

52. Fusco Girard, L.; De Rosa, F.; Nocca, F. Verso il piano strategico di una città storica: Viterbo. BDC Boll. Cent. Calza Bini 2014, 14, 11-38.

53. Colombo, L.; De Toro, P.; Acampora, A. Riqualificazione, valorizzazione e valutazione del Paesaggio Urbano Storico. Agribus. Paesaggio Ambient. 2016, 19, 40-47.

54. Throsby, D. Investment in urban heritage conservation in developing countries: Concepts, methods and data. City Cult. Soc. 2016, 7, 81-86. [CrossRef]

55. Throsby, D. The Economics of Cultural Policy; Cambridge University Press: Cambridge, UK, 2010.

56. Department for Culture Media \& Sport. The Culture White Paper; Department for Culture Media \& Sport: London, UK, 2016; ISBN 0262160935. 
57. European Association of Historic Towns and Regions (EAHTR). INHERIT Investing in Heritage-A Guide to Successful Urban Regeneration; European Association of Historic Towns and Regions: Norwich, UK, 2007.

58. United Nations Development Programme (UNDP). Creative Economy Report: Widening Development Pathways; United Nations Development Programme: New York, NY, USA, 2013; ISBN 9780981661902.

59. Belletti, G.; Berti, G. Turismo, ruralità e sostenibilità attraverso l'analisi delle configurazioni turistiche. In Differenziazione e Sentieri di Sviluppo in Toscana; Pacciani, A., Ed.; Franco Angeli: Milano, Italy, 2011.

60. UNESCO. Policy Document on the Impacts of Climate Change on World Heritage Properties; UNESCO: Paris, France, 2008.

61. Italian National Institute of Statistic (ISTAT). Il Benessere Equo e Sostenibile in Italia; BES Report 2015; Italian National Institute of Statistic: Rome, Italy, 2015; ISBN 9788845818769.

2017 by the author. Licensee MDPI, Basel, Switzerland. This article is an open access article distributed under the terms and conditions of the Creative Commons Attribution (CC BY) license (http:/ / creativecommons.org/licenses/by/4.0/). 